\title{
Agromophological Characterisation of Amaranth Accessions from Malawi
}

\author{
Mvuyeni Nyasulu' ${ }^{1}$, Abel Sefasi ${ }^{*}{ }^{*}$, Sibongile Chimzinga ${ }^{1}$, Moses Maliro² \\ ${ }^{1}$ Horticulture Department, Lilongwe University of Agriculture and Natural Resources, Bunda College, Lilongwe, Malawi \\ ${ }^{2}$ Crop and Soil Sciences Department, Faculty of Agriculture, Lilongwe University of Agriculture and Natural Resources, Bunda \\ Campus, Lilongwe, Malawi
}

Email: *asefasi@luanar.ac.mw

How to cite this paper: Nyasulu, M., Sefasi, A., Chimzinga, S. and Maliro, M. (2021) Agromophological Characterisation of Amaranth Accessions from Malawi. American Journal of Plant Sciences, 12, 1528-1542. https://doi.org/10.4236/ajps.2021.1210108

Received: July 1, 2021

Accepted: October 17, 2021

Published: October 20, 2021

Copyright (c) 2021 by author(s) and Scientific Research Publishing Inc. This work is licensed under the Creative Commons Attribution International License (CC BY 4.0).

http://creativecommons.org/licenses/by/4.0/ (c) (i) Open Access

\begin{abstract}
Five amaranth (Amaranthus spp.) accessions from central and southern region of Malawi were characterised at Lilongwe University of Agriculture and Natural Resources using agro-morphological traits. A total of thirteen descriptors, defined by Plant Genetic Resources Institute (IPGRI), were used to characterise the amaranth accessions under study. Field experiments were carried out for two seasons in August to November, 2018 and January to March, 2019. The experiments were laid out in a Randomised Complete Block Design (RCBD), which was replicated four times. The qualitative (plant growth habit, leaf colour, inflorescence colour, stem colour, inflorescence spininess, seed colour) and quantitative traits (plant height, stem girth, leaf length, leaf width, inflorescence length, days to $80 \%$ flowering, grain yield, leaf yield, and days to $80 \%$ maturity) evaluated were significant in defining the uniqueness of different amaranth accessions evaluated. Significant differences $(\mathrm{P}<0.05)$ obtained from analysis of variance were observed in all the parameters studied. Correlation analysis was conducted using Genstat statistical package version 18 while cluster analysis was done using $\mathrm{R}$ statistical software. The agro-morphological characterisation results showed a wide range of variation for most of the qualitative characters. Wide variability was present in all the qualitative characters except for plant growth habit where all the accessions exhibited erect plant growth habit. These results point to high possibility of genetic diversity of amaranth accessions in Malawi, it could be exploited in future breeding purposes and deserving conservation.
\end{abstract}

\section{Keywords}

Phenotypic Descriptors, Accession, Amaranth, Correlation Analysis, Cluster Dendrogram 


\section{Introduction}

Amaranth (Amaranthus spp.) is a "pseudo-cereal" crop with its flavour and cooking attributes similar to cereals. The crop has high nutritional and medicinal value [1]. The amaranth genus includes about 50 - 60 species cultivated both as leaf as well as for grains [2]. It is extensively cultivated as a green leaf vegetable in most tropical countries. The colour of the leaves ranges from green, purple, red and gold [3].

In terms of nutritional content, leaf and grain of amaranth species contain appreciable amounts of proteins, vitamin $\mathrm{C}$ and mineral elements. However, amaranths leaves have shown to have more nutrition content than grain [1]. Consequently, in Malawi, consumption of amaranth is almost exclusive for the leaf. As such it offers health benefits to human beings. The vegetable improves palatability and adds variety to diets. It is particularly valuable source of food during emergency periods such as occur during flood, famine, drought and war [4]. In addition, the crop leads to income generation. Socio-economic surveys in various parts of Africa have revealed that Amaranth provides employment opportunities and generates income for rural population. The market for this vegetable is increasing due to its nutritional benefits [1]. As such, any smallholder farmer involved in the production of this kind of vegetable will realise significant economic benefits.

However, amaranth is affected by many factors that limit its production. The status of the indigenous vegetables like amaranth as wild and weedy volunteer renders it unattractive for attention, especially as it is often seen as a poor man's crop [5]. This reduces consumption of this nutritious vegetable and defeats efforts conducted through 'conservation through utilisation'. Pests and diseases of Amaranth also pose serious threats to its sustainable production. Some of the common pests include: leaf miners, leaf rollers, cutworms, aphids, flea beetles, army worm and mites, and the common diseases include: damping-off [4]. Severe infestations can lead to complete yield loss as the leaves become unsuitable for marketing and consumption. Despite the challenges, the crop is gaining much attention of consumers mainly because of its nutritional quality [5]. However, limited availability of varieties, the crop has not been commercially exploited. Although this vegetable has been the source of nutrition for earlier generations, it became popular due to urbanisation and the increased demand for exotic vegetables. This vegetable has been thought as inferior and associated with poverty by the youth. However, there has been a steady rise in demand in Malawi due to nutritional campaigns and inclusion of such vegetable in climate change resilience strategies. It is therefore important to explore the possibility of commercialising such vegetable in Malawi. This will not only contribute to improved livelihoods of poor communities, but it will also indirectly contribute to improved nutrition and conservation of these valuable genetic resources.

In order for such commercialisation and conservation efforts to be sustainable it is important to understand the diversity of Amaranth in Malawi. Agro-mor- 
phological characterisation and evaluation of amaranth accessions can provide breeders with valuable information on effective utilization of genetic resources for breeding programmes [6]. Agro-morphological characterisation of cultivars has an important role in the measurement of genetic diversity hence it is necessary in effective conservation of biodiversity of amaranth and in improvement programmes of the crop [7]. Determination of genetic diversity of any given crop species is a suitable precursor for crop improvement because it provides a platform and a guide to selection of parental lines and on which breeding design is to be developed [8]. In addition, the lack of phenotypic descriptors of accessions has caused a big gap that is preventing the development of varieties of amaranth. So far there is no released variety of amaranth in Malawi, despite the crop being popular, highly nutritious and climate resilient. Importantly, the development of varieties requires clear phenotypic descriptors of a distinct and uniform collection of plants in addition to seed standards to guide quality seed production when a variety is released. For an indigenous crop with little information, comparison of various accessions under uniform environment would be an important initial step in the identification of those morphological and phenotypic characteristics that are determine by genetics. However, the importance of genetics and molecular data is only appreciated where there is evidence of its association with agro-morphological data. It is therefore a tradition that for new crops, breeding efforts rely first on characterisation at morphological level followed by genetic studies. According to various reports, the genus of amaranth exhibits a high degree of morphological diversity [4] [6] [9]. Such information is important for selecting better accession for breeding programs. So far, no distinctive study has been undertaken in Malawi to characterise amaranth accessions. The current study was undertaken to characterise amaranth accessions using agro-morphological traits under agro-climatic conditions. The results are useful in future genetic studies to improve this climate-resilient and highly nutritive underutilised crop species.

\section{Materials and Methods}

\subsection{Experimental Site}

Field experiments were conducted at Lilongwe University of Agriculture and Natural Resources, Bunda College of Agriculture for two seasons in August to November, 2018 and January to March, 2019. The university is located at $14^{\circ} 11^{\prime} \mathrm{S}$ latitude and longitude of $33^{\circ} 46^{\prime} \mathrm{E}$ at an altitude of 1100 meters above sea level. It lies within the Mid-elevation, upland plateau agro-ecological zone. The area receives an annual rainfall of about $930 \mathrm{~mm}$. The mean annual temperature is $19.1^{\circ} \mathrm{C}$ with a maximum temperature of $27.8^{\circ} \mathrm{C}$ and a minimum of $17.2^{\circ} \mathrm{C}$. The site is mostly dominated by clay loam soils.

\subsection{Amaranth Accessions Collections}

The seeds of four amaranth accessions were collected from farmers in three dis- 
tricts of Malawi (Ntcheu, Phalombe and Mwanza) while one accession was collected from the Lilongwe University of Agriculture and Natural resources in the horticulture department. The geographical coordinates of the various collection points are presented in Table 1.

\subsection{Experimental Layout and Design}

The five amaranth accessions were laid out through direct planting in a Randomised Complete Block Design (RCBD) with four replicates. The unit plot comprised of 8 ridges of 2 meters long spaced at $75 \mathrm{~cm}$ apart. One and half meters separated the replicates to maintain the genetic purity that can be affected due to cross pollination of the amaranth accessions. A plot size of $2 \mathrm{~m} \times 4.2 \mathrm{~m}$ with a net plot area of $3 \mathrm{~m}^{2}$ was used which contained 4 ridges per plot. Seeds were sown directly at a spacing of $30 \mathrm{~cm}$ between planting stations for both hot dry season and hot wet season. Thinning was done, two weeks after germination leaving one plant per planting station. A population of 56 plants per plot was maintained in each plot. $200 \mathrm{~kg} / \mathrm{ha} 23: 21: 0+4 \mathrm{~s}$ fertiliser as basal fertiliser a week after sowing was applied, and $120 \mathrm{~kg} / \mathrm{ha}$ CAN as top dressing. Acephate was applied to control pests attack. Weed control was done by hand-hoeing at 2-week intervals immediately after germination. Furrow irrigation was used thrice a week.

\subsection{Data Collection}

At the blooming stage, fifteen randomly selected plants within a net plot of $3 \mathrm{~m}^{2}$ in each plot were selected and data on both quantitative and qualitative traits were collected. The qualitative traits included; plant height $(\mathrm{cm})$ (from ground level to the highest tip of the inflorescence) using a measuring tape, stem girth $(\mathrm{cm})$ (between $3^{\text {rd }}$ and $4^{\text {th }}$ node) using a calliper, leaf length $(\mathrm{cm})$, leaf width $(\mathrm{cm})$, and inflorescence length $(\mathrm{cm})$ using a measuring tape, leaf yield $(\mathrm{kg} / \mathrm{ha})$, and grain yield $(\mathrm{kg} / \mathrm{ha})$. Leaf and grain were harvested manually in the net plot, weighed on the scale and later converted into yield $(\mathrm{kg} / \mathrm{ha})$. While days to $50 \%$ flowering and days to $80 \%$ maturity were determined by counting days from planting to the days $50 \%$ of the plants in the net plot flowered and $80 \%$ of the plants reached maturity in the net plot area. Inflorescence colour, plant growth

Table 1. Treatments, names and origins of amaranth accessions used in the experiment.

\begin{tabular}{cccccc}
\hline $\begin{array}{c}\text { Treat- } \\
\text { ments }\end{array}$ & Accession Code & Origin & $\begin{array}{c}\text { Elevation } \\
\text { (masl) }\end{array}$ & $\begin{array}{c}\text { Latitude } \\
\text { (south) }\end{array}$ & $\begin{array}{c}\text { Longitude } \\
\text { (east) }\end{array}$ \\
\hline T1 & PE-UP-BH-01 & Phalombe-Upper & 803.75 & 15.77 & 36.66 \\
T2 & PE-LO-BH-01 & Phalombe-Lower & 728.77 & 15.65 & 35.63 \\
T3 & NU-BH-01 & Ntcheu & 1422.5 & 14.67 & 34.53 \\
T4 & MN-BH-01 & Mwanza & 2529 & 15.37 & 34.29 \\
T5 & LL-BH-04 & Lilongwe & 1100 & 14.11 & 33.46 \\
\hline
\end{tabular}

masl $=$ meters above sea level. 
habit, leaf colour, stem colour, inflorescence spininess and seed colour were visually observed on all plants within in the gross plot.

\subsection{Data Analysis}

Data collected was subjected to analysis of Variance (ANOVA) using Genstat statistical package $18^{\text {th }}$ edition. Means were separated using Tukey test at $5 \%$ level of significance. Pearson Correlation analysis was conducted by the same software to determine the linear relationship between two variables. Morphological characterisation data were organised into a matrix and subjected to cluster analyses using the $\mathrm{R}$ statistical software version 2.13.0. to highlight similarities and differences among amaranths accessions.

\section{Results}

\subsection{Qualitative Traits of Amaranth Accessions}

The qualitative traits data revealed a wide range of variation for most of the characteristics studied (Table 2). Six qualitative traits were studied, and these were plant growth habit, leaf colour, inflorescence colour, seed colour, inflorescence spininess, and stem colour. All the traits studied except the plant growth habit were variable among the accessions. All the five accessions exhibited an erect plant growth habit. A number of the accessions showed green leaf colour except $\mathrm{MN}-\mathrm{BH}-01$, which had a purple leaf colour. The accessions having the green inflorescence colour were PE-UP-BH-01, PE-LO-BH-01, and LL-BH-04, while NU-BH-01 and MN-BH-01 had light green colour and purple colour respectively. Only MN-BH-01 exhibited a purple stem colour whilst the rest of the accessions exhibited green stem colour. Three of the accessions were observed to have spiny inflorescence and these were PE-UP-BH-01, PE-LO-BH-01 and LLBH-04 while NU-BH-01 and MN-BH-01 showed a smooth inflorescence. Black seed colour was predominantly observed in all the accessions except in LL-BH04 where brown seed colour was observed.

\subsection{Vegetative Traits of Amaranth Accessions}

Plant height, stem girth, leaf length, leaf width and inflorescence length were the vegetative traits that were studied. All the vegetative traits were significantly

Table 2. Qualitative traits of five amaranth accessions.

\begin{tabular}{clccccc}
\hline Accession & PGH & LC & IC & SC & IS & SDC \\
\hline PE-UP-BH-01 & Erect & Green & Green & Green & Spiny & Black \\
PE-LO-BH-01 & Erect & Green & Green & Green & Spiny & Black \\
NU-BH-01 & Erect & Green & Light-Green & Green & Smooth & Black \\
MN-BH-01 & Erect & Purple & Purple & Purple & Smooth & Black \\
LL-BH-04 & Erect & Green & Green & Green & Spiny & Brown \\
\hline
\end{tabular}

Abbreviation: $\mathrm{PGH}=$ plant growth habit, $\mathrm{LC}=$ leaf colour, $\mathrm{IC}$, inflorescence colour, $\mathrm{SC}=$ stem colour, IS = inflorescence spininess, $\mathrm{SDC}=$ seed colour. 
different among the amaranth accessions evaluated $(\mathrm{P}<0.001)$ (Table 3). In terms of plant height, the amaranth accessions evaluated were significantly $(\mathrm{P}<$ 0.001) different from each other. MN-BH-01 accession recorded the highest plant height $(263.9 \pm 11.29 \mathrm{~cm})$ and the shortest plant height was recorded in LLBH-04 accession $(105.8 \pm 2.46 \mathrm{~cm})$.

Stem girth was significantly different among all the amaranth accessions evaluated $(\mathrm{P}<0.001)$ (Table 3$)$. The highest stem girth was observed in MN-BH-01 accession $(25.6 \pm 1.94 \mathrm{~mm})$ and the lowest stem girth was observed in LL-BH-04 accession $(11.9 \pm 0.50 \mathrm{~mm})$.

All the amaranth accessions evaluated were significantly different in terms of leaf length and leaf width $(\mathrm{P}<0.001)$ (Table 3$)$. All the accessions except LLBH-01 $(12.9 \pm 0.50 \mathrm{~cm})$. Accessions PE-UP-BH-01, PE-LO-BH-01 and MN-BH01 recorded the highest leaf width with $10.2 \pm 0.27 \mathrm{~cm}, 9.3 \pm 0.57 \mathrm{~cm}$, and $9.7 \pm$ $0.29 \mathrm{~cm}$ respectively while accessions NU-BH-01 and LL-BH-01 recorded the least leaf width with $6.4 \pm 1.30 \mathrm{~cm}$ and $6.3 \pm 0.30 \mathrm{~cm}$ respectively.

Inflorescence length was significantly different in all the amaranth accessions evaluated in the study $(\mathrm{P}<0.001)$ as shown in the Table 3. Accessions PE-UP$\mathrm{BH}-01, \mathrm{PE}-\mathrm{LO}-\mathrm{BH}-01, \mathrm{NU}-\mathrm{BH}-01$ and $\mathrm{MN}-\mathrm{BH}-01$ recorded the highest inflorescence length with $50.6 \pm 4.48 \mathrm{~cm}, 53.6 \pm 4.70 \mathrm{~cm}, 54.8 \pm 4.78 \mathrm{~cm}$, and $69.4 \pm 7.36$ $\mathrm{cm}$ respectively as they were not statistically significant from each other. The least inflorescence length was observed in accession LL-BH-04 with $31.5 \pm 3.13 \mathrm{~cm}$.

Leaf yield was also significantly different $(\mathrm{P}<0.05)$ among the amaranth accessions studied (Table 3). The highest leaf yield was recorded in PE-UP-BH-01 amaranth accession with $2772 \pm 229.9 \mathrm{~kg} / \mathrm{ha}$ and this was not significantly different from PE-LO-BH-01 and NU-BH-01 amaranth accessions with $2075 \pm$ $836.7 \mathrm{~kg} / \mathrm{ha}$ and $1868 \pm 572.4 \mathrm{~kg} / \mathrm{ha}$, respectively. However, the lowest leaf yield was observed in LL-BH-04 accession with $925 \pm 206.5 \mathrm{~kg} / \mathrm{ha}$.

\subsection{Productive Traits of Amaranth Accessions}

Significant differences $(\mathrm{P}<0.05)$ were observed in all the reproductive traits that

Table 3. Vegetative traits of amaranth accessions.

\begin{tabular}{ccccccc}
\hline ACCESSION & PH $(C M)$ & SG $(M M)$ & LL $(C M)$ & LW $(C M)$ & IL $(C M)$ & LY (KG/HA) \\
\hline PE-UP-BH-01 & $166.5 \pm 3.47^{\mathrm{b}}$ & $19.7 \pm 0.54^{\mathrm{bc}}$ & $17.7 \pm 0.97^{\mathrm{b}}$ & $10.2 \pm 0.27^{\mathrm{b}}$ & $50.6 \pm 4.48^{\mathrm{ab}}$ & $2772 \pm 229.9^{\mathrm{c}}$ \\
PE-LO-BH-01 & $177.1 \pm 5.68^{\mathrm{b}}$ & $22.1 \pm 1.05^{\mathrm{cd}}$ & $19.9 \pm 0.92^{\mathrm{b}}$ & $9.3 \pm 0.57^{\mathrm{b}}$ & $53.6 \pm 4.70^{\mathrm{b}}$ & $2075 \pm 836.7^{\mathrm{bc}}$ \\
NU-BH-01 & $206.5 \pm 7.07^{\mathrm{c}}$ & $17.6 \pm 0.89^{\mathrm{b}}$ & $19.1 \pm 1.24^{\mathrm{b}}$ & $6.4 \pm 1.30^{\mathrm{a}}$ & $54.8 \pm 4.78^{\mathrm{b}}$ & $1868 \pm 572.4^{\mathrm{abc}}$ \\
MN-BH-01 & $263.9 \pm 11.29^{\mathrm{d}}$ & $25.6 \pm 1.94^{\mathrm{d}}$ & $18.6 \pm 0.70^{\mathrm{b}}$ & $9.7 \pm 0.29^{\mathrm{b}}$ & $69.4 \pm 7.36^{\mathrm{b}}$ & $1589 \pm 158.7^{\mathrm{ab}}$ \\
LL-BH-04 & $105.8 \pm 2.46^{\mathrm{a}}$ & $11.4 \pm 0.45^{\mathrm{a}}$ & $12.9 \pm 0.50^{\mathrm{a}}$ & $6.3 \pm 0.30^{\mathrm{a}}$ & $31.5 \pm 3.13^{\mathrm{a}}$ & $925 \pm 206.5^{\mathrm{a}}$ \\
P VALUE & $<0.001$ & $<0.001$ & $<0.001$ & $<0.001$ & $<0.001$ & $<0.001$ \\
CV\% & 24.3 & 38.3 & 33.1 & 50.3 & 64.8 & 15.6 \\
LSD $_{(0.05)}$ & 19.47 & 3.210 & 2.532 & 1.836 & 7.423 & 671.59 \\
\hline
\end{tabular}

Means followed by the same letters in a column are not statistically different at $\mathrm{P}<0.05$. Abbreviation: $\mathrm{PH}=$ plant height, $\mathrm{SG}$, stem girth, $\mathrm{LL}=$ leaf length, $\mathrm{LW}$, leaf width, $\mathrm{IL}=$ inflorescence length. 
were evaluated among the amaranth accessions (Table 3). Analysis of variance $($ ANOVA) result indicated that there was significant $(\mathrm{P}<0.05)$ differences at in grain yield among the amaranth accessions evaluated (Table 4 ). The highest mean grain yield was observed in LL-BH-04 amaranth accession (5699 \pm 112.7 $\mathrm{kg} / \mathrm{ha}$ ). On the other hand, the lowest grain yield was recorded in NU-BH-04 accession with $1367 \pm 46.6 \mathrm{~kg} / \mathrm{ha}$.

Analysis of variance result also indicated significant differences $(\mathrm{p}<0.05)$ in days to $50 \%$ flowering and days to $80 \%$ maturity (Table 4 ). NU-BH-01 accession took many days to reach $50 \%$ flowering (121 \pm 3.1 days) while LL-BH-04 accession took few days to reach $50 \%$ flowering (78 \pm 2.2 days). Those amaranth accessions that took many days to reach $50 \%$ flowering also took many days to reach $80 \%$ maturity. NU-BH-01 and $\mathrm{MN}-\mathrm{BH}-01$ accessions took many days to reach $80 \%$ maturity with $144 \pm 3.5$ days and $140 \pm 3.4$ days respectively. LL-BH-04 accession took few days to reach $80 \%$ maturity with $104 \pm 3.0$ days.

\subsection{Correlation Coefficients among Growth, Vegetative and Reproductive Traits in Amaranth Accessions}

There were significant $(\mathrm{P}<0.05)$ and positive correlations between most of the quantitative variables (Table 5). Inflorescence length was highly correlated with leaf length $\left(r=0.8623^{*}\right)$, plant height $\left(r=0.9807^{\star}\right)$, stem girth $\left(r=0.9422^{\star}\right)$, days to $50 \%$ flowering $\left(r=0.7129^{*}\right)$, days to $80 \%$ maturity $\left(r=0.8857^{\star}\right)$, and grain yield $\left(r=0.8854^{*}\right)$. Leaf length was also highly correlated with plant height $(\mathrm{r}=$ $\left.0.8857^{\star}\right)$, stem girth $\left(\mathrm{r}=0.7456^{\star}\right)$, days to $50 \%$ flowering $\left(\mathrm{r}=0.7135^{\star}\right)$, and days to $80 \%$ maturity $\left(r=0.7994^{\star}\right)$. Meanwhile in leaf length and leaf width recorded a high significant $(\mathrm{p}<0.05)$ negative correlation $\left(\mathrm{r}=-0.1241^{\star}\right)$ as well as between leaf length and leaf yield $\left(\mathrm{r}=-0.0568^{\star}\right)$ and between leaf width and grain yield $\left(\mathrm{r}=-0.7535^{\star}\right)$. Leaf width was significantly correlated with stem girth $(\mathrm{r}=$ $\left.0.5624^{*}\right)$ and days to $50 \%$ maturity $\left(r=-0.1070^{*}\right)$. Plant height was also significantly positively correlated with stem girth $\left(\mathrm{r}=0.9242^{\star}\right)$, days to $50 \%$ flowering $\left(\mathrm{r}=0.7337^{\star}\right)$, and days to $80 \%$ maturity $\left(\mathrm{r}=0.8870^{\star}\right)$, while it was significantly

Table 4. Reproductive traits of amaranth accessions.

\begin{tabular}{cccc}
\hline ACCESSION & GY (KG/HA) & D50F & D80M \\
\hline PE-UP-BH-01 & $4425 \pm 239.0^{\mathrm{c}}$ & $104 \pm 3.7^{\mathrm{b}}$ & $124 \pm 3.6^{\mathrm{b}}$ \\
PE-LO-BH-01 & $1797 \pm 87.6^{\mathrm{a}}$ & $103 \pm 1.1^{\mathrm{b}}$ & $124 \pm 1.4^{\mathrm{b}}$ \\
NU-BH-01 & $1367 \pm 46.6^{\mathrm{a}}$ & $121 \pm 3.1^{\mathrm{d}}$ & $144 \pm 3.5^{\mathrm{c}}$ \\
MN-BH-01 & $2722 \pm 64.5^{\mathrm{b}}$ & $110 \pm 2.6^{\mathrm{c}}$ & $140 \pm 3.4^{\mathrm{c}}$ \\
LL-BH-04 & $5699 \pm 112.7^{\mathrm{d}}$ & $78 \pm 2.2^{\mathrm{a}}$ & $104 \pm 3.0^{\mathrm{a}}$ \\
P VALUE & $<0.001$ & $<0.001$ & $<0.001$ \\
CV\% & 16.2 & 5.7 & 4.1 \\
LSD $_{(0.05)}$ & 620.3 & 3.706 & 3.257 \\
\hline
\end{tabular}

Means followed by the same letters in a column are not statistically different at $\mathrm{P}<0.05$. Abbreviation: GY = grain yield, $\mathrm{LY}$, leaf yield, $\mathrm{D} 50 \mathrm{~F}=$ days to $50 \%$ flowering, $\mathrm{D} 80 \mathrm{M}=$ days to $80 \%$ maturity. 
Table 5. Pearson correlation between the quantitative variables.

\begin{tabular}{cccccccccc}
\hline Traits & IL & LL & LW & PH & SG & D50F & D80M & LY & GY \\
\hline IL & & & & & & & & \\
LL & $0.8623^{*}$ & & & & & & & \\
LW & 0.3214 & $-0.1241^{*}$ & & & & & & \\
PH & $0.9807^{*}$ & $0.8989^{*}$ & 0.2452 & & & & & \\
SG & $0.9422^{*}$ & $0.7456^{*}$ & $0.5624^{*}$ & $0.9242^{*}$ & & & & \\
D50F & $0.7129^{*}$ & $0.7135^{*}$ & $-0.1070^{*}$ & $0.7337^{*}$ & $0.5765^{*}$ & & & \\
D80M & $0.8857^{*}$ & $0.7994^{*}$ & 0.1077 & $0.8870^{*}$ & $0.7726^{*}$ & $0.8506^{*}$ & & \\
LY & 0.0231 & $-0.0568^{*}$ & 0.1132 & 0.0351 & 0.0722 & 0.2327 & 0.0307 & \\
GY & $0.8854^{*}$ & $-0.7535^{*}$ & 0.1994 & $-0.6120^{*}$ & $-0.5112^{*}$ & $-0.6802^{*}$ & $-0.6749^{*}$ & $-0.1743^{*}$ & \\
\hline
\end{tabular}

* = Significant at $\mathrm{P}<0.05$, Abbreviations represent; Inflorescence length $=\mathrm{IL}$, leaf length $=\mathrm{LL}$, leaf width $=$ $\mathrm{LW}$, plant height $=\mathrm{PH}$, stem girth $=\mathrm{SG}$, Days to $50 \%$ flowering $=\mathrm{D} 50 \mathrm{~F}$, Days to $80 \%$ maturity $=\mathrm{D} 80 \mathrm{M}$, leaf yield $=\mathrm{LY}$, grain yield $=\mathrm{GY}$,

negatively correlated with grain yield $\left(\mathrm{r}=-0.6120^{\star}\right)$. Stem girth was highly correlated with days to $50 \%$ flowering $\left(r=0.5765^{\star}\right)$, days to $80 \%$ maturity $(r=$ $\left.0.7726^{*}\right)$, while stem girth and grain yield recorded a significant $(\mathrm{P}<0.05)$ negative correlation $\left(\mathrm{r}=-0.5112^{\star}\right)$. Significant $(\mathrm{P}<0.05)$ positive correlation was also observed between days to $50 \%$ flowering and days to $80 \%$ maturity ( $\mathrm{r}=$ $\left.0.8506^{*}\right)$ and days to $50 \%$ flowering and grain yield recorded a significant $(\mathrm{P}<0.05)$ negative correlation $\left(\mathrm{r}=-0.6802^{*}\right)$ as well as between days to $80 \%$ maturity and grain yield $\left(r=-0.6749^{\star}\right)$ and between leaf yield and grain yield $\left(r=-0.1743^{\star}\right)$.

\subsection{Agro-Morphological Characteristics}

Results of the cluster analysis of morphological traits studied are shown in Figure 1. Thirteen agro-morphological traits observed during the study, indicated similarities in plant growth habit with erect growth habit and leaf width. Cluster dendrogram analysis grouped the amaranths accessions evaluated in two main clusters according to their similarities (Figure 1). The differentiation was based on two main criteria, one was group branching of the dendrogram and secondly the magnitude of the similarity identified by the horizontal line making the branches (Figure 1). Considering group branching, two main groups were made (cluster 1 and 2, and cluster 3. For using second criteria on magnitude of the similarities, cluster 2 is closer to cluster 3 than cluster 1, where by PE-UP-BH-01, and PE-LO-BH-01 amaranth accessions members in cluster 1 were more similar to each other. These amaranth accessions were characterised by green stem, green inflorescence and seed colour. Cluster 2 consisted of LL-BH-04 accession and was characterised mainly by brown seed, short days to reach $50 \%$ flowering and $80 \%$ maturity, short plant height and high grain yield. While cluster 3 consisted of $\mathrm{MN}-\mathrm{BH}-01$ and NU-BH-01 accessions and were mainly characterised by purple inflorescence, purple stem, purple leaves, inflorescence length of 115 $\mathrm{cm}$, tall plant height of $330 \mathrm{~cm}$, and big stem of $3.7 \mathrm{~cm}$ (Figure 2). Table 6 indicates 

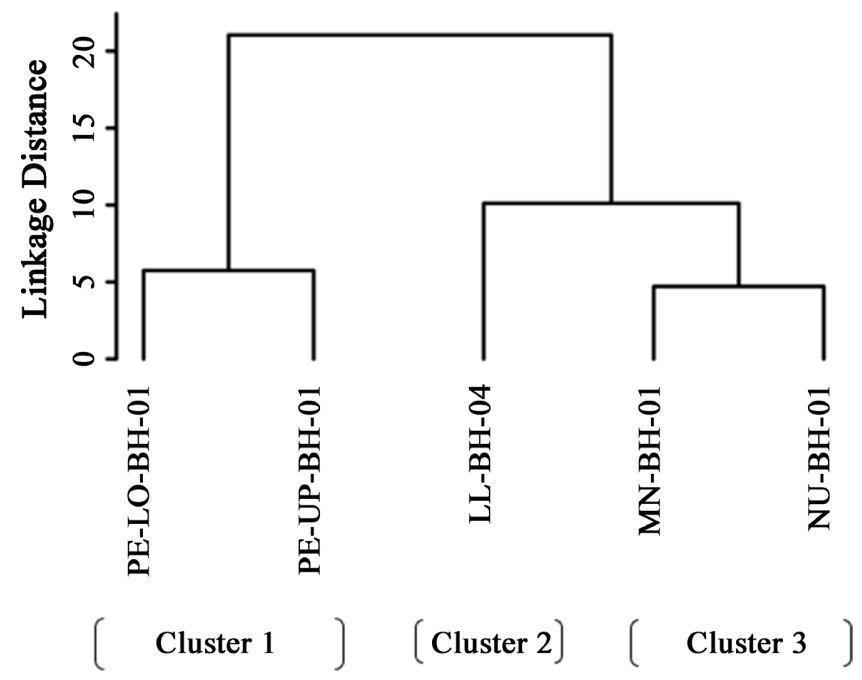

Figure 1. Cluster dendrogram on morphological characteristics in five amaranth accessions.

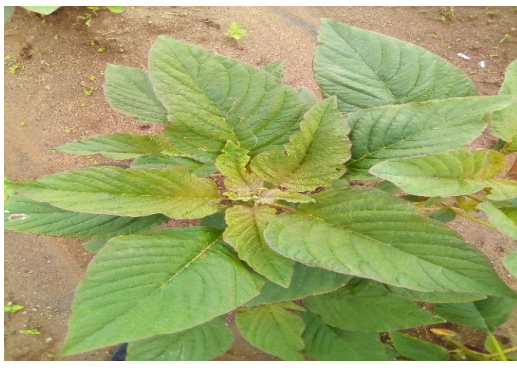

(a)

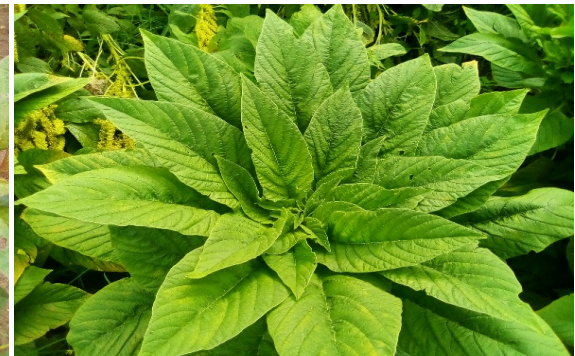

(b)

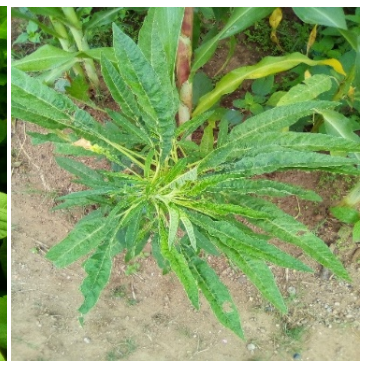

(c)

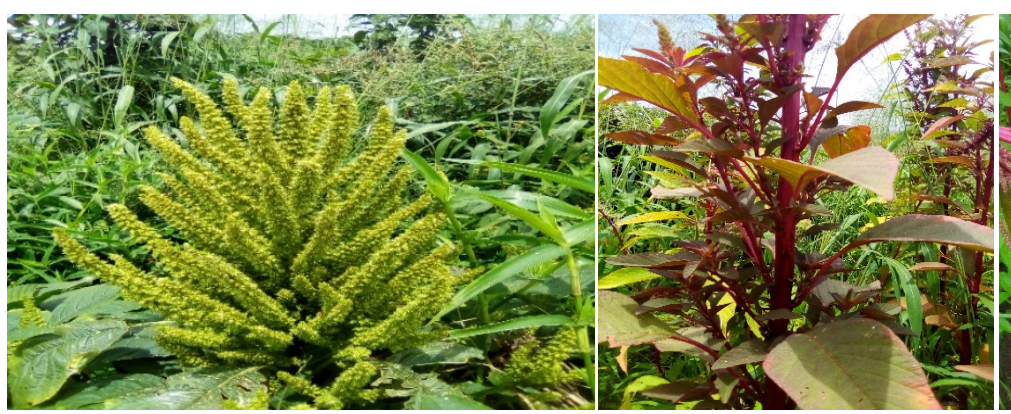

(d)

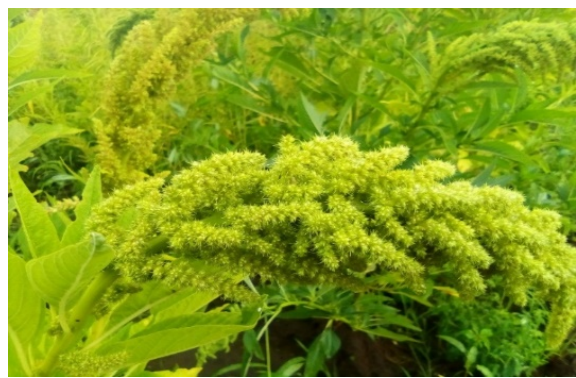

(g) (e)

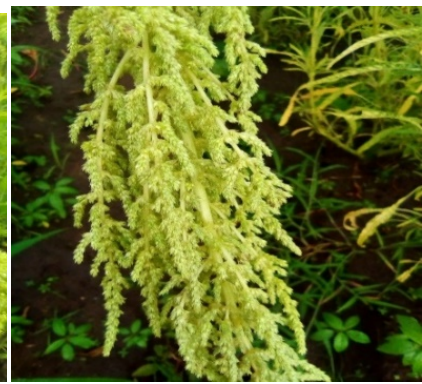

(h)

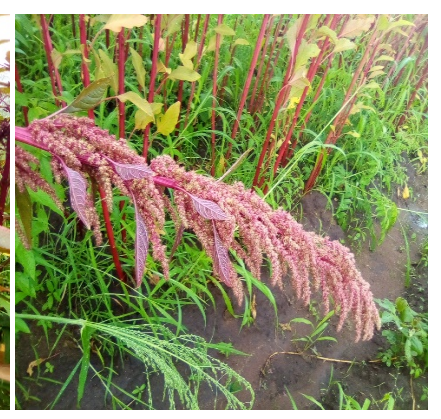

(f)

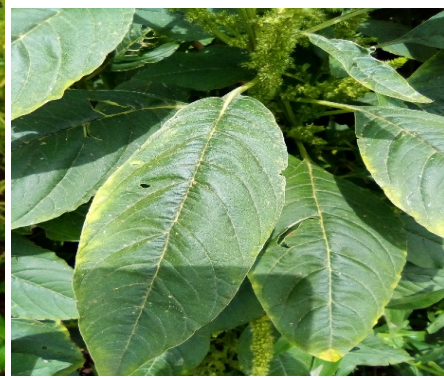

(i)

Figure 2. Amaranth accessions exhibiting diversity of qualitative traits; (a) ovate leaves (MN-BH-01), (b) leaf pattern (PE-LO-BH-01), (c) lanceolate leaves (NU-BH-01), (d) green inflorescence with spines (LL-BH-04), (e) purple leaves and purple stem (MN-BH-01), (f) purple inflorescence colour (MN-BH-01), (g) green inflorescence with spines (PEUP-BH-01), (h) green smooth inflorescence (NU-BH-01), (i) green leaves with yellow margin (LL-BH-04). 
Table 6. Mantel test for association between genetic distance and physical distance.

\begin{tabular}{ccc}
\hline Parameter & r value & P value \\
\hline Grain yield & 0.0324 & 0.624 \\
Leaf yield & 0.0170 & 0.170 \\
Days to 50\% flowering & 0.0133 & 0.071 \\
Days to 80\% maturity & 0.0389 & 0.084 \\
Stem girth & -0.179 & 0.963 \\
Plant height & -0.182 & 0.900 \\
Leaf length & -0.1916 & 0.919 \\
Leaf width & -0.0962 & 0.579 \\
Inflorescence length & -0.3431 & 0.6288 \\
\hline
\end{tabular}

mantel analysis depicting the relationship between genetic distance and physical distance. The results showed that there is no association between genetic traits and geographical distance at $\mathrm{P}<0.05$.

\section{Discussion}

The major objective of this study was to agro-morphologically characterise amaranth accessions collected from different districts of Malawi. Significant variation was observed for all the qualitative traits among the five amaranth accessions (Table 2). A wide range of variation for qualitative traits was also reported by [7]. An erect plant growth habit was observed in all the accessions evaluated. Leaf, stem and inflorescence colour exhibited a wide range of variation with green and purple as predominant classes while seed colour exhibited black and brown seed colour. Inflorescence spininess also exhibited a wide range of variation with smooth and spininess as predominant classes. These results might be attributed to genetic differences among the accessions evaluated since they were evaluated in the same environment. [10] reported that a wide range of pigmentation in amaranth species were due to various expressions of betacyanin pigments. More than six major genes have been identified that determine patterns of pigment expression [10]. This indicated that in the present study, the accessions contained different major genes that expressed a wide variation in terms of inflorescence, stem, leaf and seed colours. The authors investigated twenty-seven diverse genotypes of vegetable Amaranth collected from different agro-climatic regions of India. Although the accessions investigated were from other species than the ones evaluated in the current study, the behaviour of these qualitative traits has been shown not to vary since they are from the same family [11].

The qualitative traits have been regarded as beneficial for characterising species germplasm [12]. These have an impact on the preference of the consumers, socio-economic scenario and natural selection as they determine the particular traits that can be found in the society. For instance, most Africans prefer to in- 
clude the green-leaved varieties in their diet while the Chinese prefer the redleaved varieties [2].

The analysis of vegetative traits exhibited significant differences $(P<0.05)$ for five characters indicating the existence of variability for these characters among the amaranth accessions studied (Table 3). Plant height ranged from $105.8 \mathrm{~cm}$ to $263.9 \mathrm{~cm}$. MN-BH-01 accession recorded the highest plant height, while LL-BH04 accession recorded the least plant height. $\mathrm{MN}-\mathrm{BH}-01$ accession also recorded the highest inflorescence length, and stem girth. NU-BH-01 accession recorded the highest leaf length and the lowest leaf width. These differences observed among the amaranth accessions might be due to genetic and not environmental as they were assessed on uniform environment. This observation apparently contrary to what is stated by [13], that the vegetative traits diversity was due to environment. This is so because the experiment was conducted in their natural environment.

There was a great variation in all the reproductive traits evaluated in all the amaranth accessions (Table 4). Grain yield was maximum in LL-BH-04 accession with $5699 \mathrm{~kg} / \mathrm{ha}$. This was attributed to the fact that the accession has gone through intensive selection process than other accessions used in the study. This has been cultivated for more than 20 years at Bunda for research and seed multiplication. Selection is a pre-requisite to breeding, which basically discriminates among biological variation in a population to identify and pick desirable variants with the aim of advancing desirable variants [14]. Certainly, LL-BH-04 due to intensive selection practices across many generations appeared to have generated a significant degree of differentiation and, thus giving rise to a significant number of local variants with the interesting features used in the study like grain yield. Similar observations were reported by [15] in Ghana Eggplant. This has important implications for germplasm management and breeding of improved varieties.

Amaranth grain yield strongly depends on environment, weather conditions, species, genotype and production techniques [13]. Since the environment, weather conditions, and production techniques were all the same in all the accessions evaluated, this indicates that the variations in terms of grain yield were only due to genotype.

Significant variations were also observed in days to $50 \%$ flowering and days to $80 \%$ maturity (Table 4). NU-BH-01 accession took many days to reach 50\% flowering as well as days to $80 \%$ maturity with 121 days and 144 days respectively. This might also be attributed to genetic differences among the amaranth accessions studied. Early flowering in amaranth is governed by a single gene, with the dominant allele determining earliness in flowering [10]. Late flowering and maturity has been reported to be an advantage to vegetable amaranths since farmers would have a longer time to harvest the leaves [2]. In Malawi, amaranth is almost exclusively utilised as a leafy vegetable [1]. However, early flowering and maturity would be more advantageous for grain production.

The variation in days to $50 \%$ flowering and $80 \%$ maturity might be attributed 
to the differences in genotypes since the accessions were evaluated on the same environment. This indicates that the genotypic coefficient of variation and phenotypic coefficient of variation were very high. This explains that the heritability in broad sense as well as genetic advance were also very high. As such, it is concluded that there was a prevalence of additive gene action in their inheritance. Thus, selection for such traits can easily be done. This agrees with the report of [16] that high heritability of characters is an indication that superior genotypes could be reliably selected on the basis of phenotypic performance.

Morphological variability studies provide information on the extent of improvement in different characters; however, they do not give much attention regarding the extent and nature of relationship existing between characters. As such, for rational approach towards the improvement of yield, selection has to be made for the components of yield, since there may not be genes for yield, but only for yield components. Genetic correlations between two characters arise because of linkage, pleiotropy or developmentally induced functional relationship [17]. Hence, it has greater significance and could be effectively utilized in formulating an effective selection scheme. For instance, if the trait choice does not provide better grounds for discriminative selection, other variables or traits that are positively correlated with the target trait can be used for selection. As such it is important to understand the direction of association between traits because it could help so much during selection process. During the study a narrow difference between the genotypic and phenotypic correlation coefficients was observed for various traits in the present findings and thus indicates the lesser influence of environment in the expression of these traits and presence of strong inherent association among the traits. Similar findings were also reported by [17]. Grain yield exhibited a highly significant and positive association with inflorescence length. The traits like leaf length, plant height, stem girth, days to $50 \%$ flowering and $80 \%$ maturity, and leaf yield exhibited a negative and significant association with grain yield. The results suggest the possibility of simultaneous improvement of these traits in improving grain yield. Similar results were reported by [17].

Cluster analysis is a good measure of diversity among and within species as it groups similar entries under one cluster. Cluster analysis of accessions for morphological traits showed two major clusters (Figure 1). First cluster contained three accessions. The first was subdivided into two sub-clusters based on trait values like leaf yield, days to $50 \%$ flowering, days to $80 \%$ maturity, and qualitative traits like plant growth habit, inflorescence colour, stem colour, and leaf colour. The second major cluster was subdivided into one cluster based on qualitative trait like inflorescence colour, stem colour and leaf colour. These results confirmed that there is no association between the accessions and geographical origin as indicated by mantel analysis (Table 5). [18] and [19] observed the same who compared different species of amaranth and African nightshade, respectively, and they found no association between cultivars and their origin. 
Lowest dissimilarity observed between PE-LO-BH-01 and PE-UP-BH-01, in the current study, may be due to narrow selection area. These two accessions were collected in neighbouring Extension Planning Areas (EPAs) of the same district. Mantel analysis (Table 5) also indicated that there was no association between genetic distance and physical distance. This could mean that the differences observed in accessions might be due to genetics only. Whether these two accessions are genetically similar can only be validated by taxonomic and molecular studies. However, the second cluster was mainly characterized by higher grain yield, whereas the accession in the third cluster had lower grain yield. Thus, the accessions from second cluster could be utilized in breeding programme for improvement of grain yield in Amaranth.

Cluster analysis has proved to be an effective method in grouping germplasm with common morphological traits. The dendrogram indicated genetic diversity of germplasm within and between cluster groups. It showed variations in quantitative characters such as plant height, inflorescence length and leaf size, stem girth that led to the identification of small, intermediate and large plant types among clusters. High variability of qualitative characters was also evident such as stem colour, leaf colour, inflorescence colour, inflorescence spininess and seed colour. Furthermore, accessions having desirable traits can be hybridized with other promising accessions to produce the desired hybrid after fixing following recurrent selections. Thus, the present characterization information enhances the utilization of the amaranth germplasm in breeding programs, and in ensuring efficient management of germplasm collection.

The existing inter-specific diversity between accessions is the key to crop improvement [19] and this is because cultivars with superior yield traits can be developed through breeding for improved vegetable productivity.

\section{Conclusion}

The study revealed a significant level of morphological diversity between and within amaranth accessions. However, there is potential of selection for particular traits of agronomic importance including grain yield, leaf yield, days to 50\% flowering and days to $80 \%$ maturity. These traits can be targeted for subsequent hybridization between and within two amaranth accessions for crop improvement. Uniformity in phenotypic traits such as plant growth habit, leaf colour, inflorescence colour, stem colour, inflorescence spininess and seed colour is of little taxonomic significance in the characterization of the two species as these traits cannot be effectively used to discriminate between the two species since they vary between species. This study sets the basis of genetic improvement of amaranths in Malawi since the observed diversity can be exploited in selection and crop improvement. The authors recommend further analysis of genetic diversity using molecular markers to provide comprehensive understanding from the existing variability. Future studies should also consider a relatively higher

number of accessions per species in order to increase the chances of identifying 
unique traits that can be used to clearly distinguish between the two species.

\section{Acknowledgements}

The study was implemented with financial support from Capacity Building and Management of Climate Change (CABMACC) through the Horticulture department of the Lilongwe University of Agriculture and Natural Resources (LUANAR), Bunda College Campus. The authors are grateful to the support from the administrators at CABMACC and technical staff at Horticulture Department Students' farm.

\section{Declarations}

\section{Funding}

The study was supported by Capacity Building and Management of Climate Change (CABMACC) project number: CABMAC 001-2015, through the Horticulture Department of the Lilongwe University of Agriculture and Natural Resources (LUANAR), Bunda College Campus.

\section{Availability of Data and Material}

Raw data were generated at Lilongwe University of Agriculture and Natural Resources (LUANAR), Bunda College Campus. Derived data supporting the findings of this study are available from the corresponding author (A.S.) on request.

\section{Conflicts of Interest}

The authors declare no conflicts of interest regarding the publication of this paper.

\section{References}

[1] Kachiguma, N.A., Mwase, W., Maliro, M. and Damaliphetsa, A. (2015) Chemical and Mineral Composition of Amaranth (Amaranthus L.) Species Collected from Central Malawi. Journal of Food Research, 4, 92-102. https://doi.org/10.5539/jfr.v4n4p92

[2] Akaneme, F. and Ani, G.O. (2013) Morphological Assessment of Genetic Variability among Accessions of Amaranthus hybridus. World Applied Sciences Journal, 28, 568-577.

[3] Khurana, D.S. and Kaur, S.J. (2013) Genetic Variability, Correlation and Path Coefficient Analysis in Amaranthus. Vegetable Science, 40, 238-240.

[4] Mng'omba, S.A., Kwapata, M.B. and Bokosi, J.M. (2003) Performance of Grain Amaranth Varieties under Drought Stressed Conditions in Two Contrasting Agro-Ecological Areas in Malawi. Acta Horticulturae, 618, 313-319. https://doi.org/10.17660/ActaHortic.2003.618.36

[5] Stoilova, T., Dinssa, F.F., Ebert, A.W. and Tenkouano, A. (2015) The Diversity of African Leafy Vegetables: Agromorphological Characterization of Subsets of AVRDC's Germplasm Collection. Acta Horticulturae, 1102, 67-74.

https://doi.org/10.17660/ActaHortic.2015.1102.7 
[6] Molin, W.T. and Nandula, V.K. (2017) Morphological Characterization of Amaranthus palmeri $\mathrm{x}$ A. spinosus Hybrids. American Journal of Plant Sciences, 8, 14991510. https://doi.org/10.4236/ajps.2017.86103

[7] Shah, L.R., Afroza, I.B., Khan, S.H. and Habib, M. (2018) Morphological Characterization of Amaranthus spp. under Temperate Environment Using NBPGR Descriptor. Pharmacognosy and Phytochemistry, 7, 2716-2718.

[8] Diouf, M., Kanté, A. and Mbengue, N.B. (2007) African Leafy Vegetables-Agromorphological Characterization and Participatory Plant Breeding on Four Species. Acta Horticulturae, 752, 175-178. https://doi.org/10.17660/ActaHortic.2007.752.27

[9] Srivastava, R. (2015) Assessment of Morphological Diversity of Selected Amaranthus Species. Journal of Global Science, 4, 2-4.

[10] Brenner, D.M., Baltensperger, D.D., Kulakow, P.A., Lehmann, J.W., Myers, R.L., Slabbert, M.M., et al. (2010) Genetic Resources and Breeding of Amaranthus. In: Janick, J., Ed., Plant Breeding Reviews, Vol. 19, John Wiley \& Sons, Inc., Hoboken, 227 285. https://doi.org/10.1002/9780470650172.ch7

[11] Rinchen, T., Singh, N., Maurya, S.B., Soni, V., Phour, M. and Kumar, B. (2017) Morphological Characterization of Indigenous Vegetable (Atriplex hortensis L.) from Trans-Himalayan Region of Ladakh (Jammu and Kashmir), India. Australian Journal of Crop Science, 11, 258-263. https://doi.org/10.21475/ajcs.17.11.03.pne261

[12] Gerrano, A.S., van Rensburg, W.S.J. and Adebola, P.O. (2015) Genetic Diversity of Amaranthus Species in South Africa. South African Journal of Plant and Soil, 32, 39-46. https://doi.org/10.1080/02571862.2014.973069

[13] Mwase, W.F., Kachiguma, N., Manduwa, D. and Maliro, M.F.A. (2014) Agromorphological Diversity of Amaranthus Species in Central Malawi. International Journal of AgriScience, 4, 235-241.

[14] Acquaah, G. (2012) Principles of Plant Genetics and Breeding. John Wiley \& Sons, Ltd., Hoboken. https://doi.org/10.1002/9781118313718

[15] Nyadanu, D., Aboagye, L.M., Akromah, R. and Dansi, A. (2015) Agro-Biodiversity and Challenges of On-Farm Conservation: The Case of Plant Genetic Resources of Neglected and Underutilized Crop Species in Ghana. Genetic Resources and Crop Evolution, 63, 1397-1409. https://doi.org/10.1007/s10722-015-0327-2

[16] Thapa, R. and Blair, M. (2018) Morphological Assessment of Cultivated and Wild Amaranth Species Diversity. Agronomy, 8, Article No. 272.

https://doi.org/10.3390/agronomy8110272

[17] Sagar, K.P., Hanchinamani, C.N., Imamsaheb, S.J., Nishani, S. and Ramanagouda, S.H. (2018) Genotypic Correlation Coefficients among Growth, Yield and Quality Parameters in Amaranthus Genotypes (Amaranthus tricolor L.). International Journal of Current Microbiology and Applied Sciences, 7, 2701-2707. https://doi.org/10.20546/ijcmas.2018.708.282

[18] Mbwambo, O., Abukutsa Onyango, M.O., Dinssa, F.F. and Ojiewo, C. (2015) Performances of Elite Amaranth Genotypes in Grain and Leaf Yields in Northern Tanzania. Journal of Horticulture and Forestry, 7, 16-23. https://doi.org/10.5897/JHF2014.0377

[19] Wesonga, L.N. (2014) Morphological and Genotypic Characterization of African Nightshade Cultivar. PhD Thesis, University of Nairobi, Nairobi. 